\title{
Antioxidant, Antimicrobial and Anticancer Activities of Egyptian Conocarpus erectus L. leaves Extracts
}

Ghada H.H. Ismaiel

Food Technology Research Institute (FTRI), Agricultural Research Center (ARC), Giza, Egypt

\footnotetext{
Conocarpus erectus L. (Family Combretaceae) is a low branching evergreen shrub or tree with a typical height of up to 6 meters, growing spread in Egypt. It contains phenols such as flavonoids and tannins as major constituents. Folk remedy has used parts of this species in its native countries, showed high antioxidant, antimicrobial and anticancer activity due to the presence of phenolic compounds. . In this study, the antioxidants, antimicrobial and anticancer activity of three different extracts (ethanolic, cold aqueous and hot aqueous) from leaves of this plant were assessed. The antioxidant properties of all extracts were found to be associated with the total content of phenolic compounds. Also showed high free radical scavenging activity toward DPPH radical, it could be used the hot and cold water extracts as an effective natural antioxidant. The different extracts were subjected to chromatographic fractionation with highperformance liquid chromatography. The major and sharp peaks in each sample were identified or tentatively identified based on matching with some standard compounds. Pyrogallol, caffeine and e- vanillic were the major phenolic compounds in ethanolic extract 3500, 730 and $1020 \mathrm{ppm}$,respectively but the major phenolic compounds in cold aqueous extract were pyrogallol, salicylic, epi- catachin, gallic and protocatchouic 870, 320, 210, 163 and $110 \mathrm{ppm}$ ,respectively. The extracts were also assessed against two gram-positive bacteria (Bacillus ceries, Staphylococcus aureus) and two gram-negative bacteria (Escherichia coli, Salmonella typhimurium). Nevertheless results showed all the extracts possess antibacterial activity, while the extracts of crude leaf were more active in cold aqueous of hot aqueous in case of Staph. aureus. The cytotoxic activity of these were measured, the most efficient cytotoxic activity against (breast cancer) MCF7 in ethanolic extract with IC50 $=99$ followed by hot aqueous extract (HAE) with IC50 $=100$ then cold aqueous extract (CAE) with IC50 $=102$, while the most efficient cytotoxic activity against (liver cancer) HEPG2 in hot aqueous extract with IC50 $=37.9$ followed by ethanolic extract with IC50 $=39.3$ then cold aqueous extract with IC50 $=50.9$. From previous results can be utilization from leaves extract as a natural food additives.
}

\section{Introduction}

Natural products from some of these natural resources continue to be used in pharmaceutical preparations either as crude extracts, fractions, pure compounds or analogous compounds from highly active isolated compounds (Abdel-Hameed et al., 2012).

The World Health Organization (WHO) indicated that medicinal plants are every plant which, in one or more of its structures, contains elements that may be utilized for helpful purposes, or which are forerunners for chemopharmaceutical semi synthesis (Saroya et al., 2011). The therapeutic plants may either be the wild or the developed plant particularly for restorative purposes. As there are broad home grown pharmaceuticals accessible in the present time, the alike material may be characterized in various structures, for example the powdered plant material may be measured as both a natural material and/or herbal preparation and when it's accessible in a form of the packing material, it's considered as home grown restorative product (Daniela et al., 2016). In every an herbal preparations, it's easy to systematize in terms of a defined amount and concentration of an active components, if the medicinally active constituents have been recognized and are notable. The herbal drugs are the more extensive term which embraces herbs, herbal preparations, and materials counting an ended herbal product (WHO ,2007). 
Medicinal plants are the richest bio-resource of drugs of traditional medicines, modern medicines, nutraceuticals, food supplements, folk medicines, pharmaceutical intermediates and chemical entities for synthetic drugs (Nirmala et al., 2011). Due to the multitargeting effect, inexpensive and safety of plant-based products compared to synthetic agents, there is a need for more and more searching and discovering of new drugs from plants.

Conocarpus erectus $\mathrm{L}$. is one of two species in the genus Conocarpus, in the family Combretaceae growing on shorelines in tropical and subtropical regions around the world. Conocarpus erectus; known in English as buttonwood or button mangrove; is an evergreen tree $6 \mathrm{~m}$ tall with spreading crown, grey or brown bark, glaucous medium-green leaves and greenish flowers in dense cone-like heads in terminal panicles (Bailey, 1976). It is used in some countries as folk remedy for anemia, catarrh, conjunctivitis, diabetes, diarrhea, headache, gonorrhea, bleeding, tumors, syphilis and fever (Irvine, 1961 ). The leaves were eaten or boil water and drunk to treat fever (Duke and Wain, 1981). This plant may have great relevance in the prevention and therapies of diseases in which oxidants or free radicals are implicated after more in vivo studies (Abdel-Hameed et al., 2013). The extract of C. erectus from different parts (leaves, stems, fruits, and flowers) showed high antioxidant, hepatoprotective and anticancer activity due to the presence of phenolic compounds. It is an attempt to review the pharmacognostic characteristics, traditional uses, phytochemistry and biological activities of the plant. (Maryam et al., 2015). Extracts of different parts of $C$. erectus investigated antimicrobial activity against gram-positive, gramnegative, acid-fast bacteria and fungi. The broadspectrum antibacterial activity of the plant extracts, confirms its use as a health remedy in folklore medicine (Shohayeb et al., 2013).

In this work, a phytochemical study of leaves of C. erectus and their biological activities as antioxidant, antibacterial and anticancer were done. as is the main aim in this research.

\section{Materials and Methods}

\section{Materials}

- Plant material: Conocarpus erectus L. leaves were collected from Horticultural Research Institute, Agricultural Research Center, El-Giza Governorate, Egypt. They were carefully washed with tap water. Stems were removed and the green tissue was dried at room temperature and pulverized into powder with an electric blender .

- Standards: All authentic standards were obtained from Sigma Chemical Co. (St. Louis, MO, USA). The stock standard solutions were prepared by dissolving the standard phenolic compounds and flavonoids in the appropriate volume of $50 \%$ aqueous methanol to produce a final concentration of $1 \mathrm{mg} / \mathrm{ml}$. Stock/working solutions of the standards were stored in the dark at $-18^{\circ} \mathrm{C}$.

\section{Bacterial strains}

- Cultures were prepared for in vitro antibacterial assay of the four bacteria strains, two Gram positive: Bacillus ceries (ATCC33018); and Staph. Aureus (DSM 20231) and two Gram negative Escherichia coli (ATCC69337) and salmonella typhimurium (ATCC14028). Those strains were provided by Microbiologics ${ }^{\circledR}$ USA. Tested organisms were sub cultured on nutrient agar (Oxoid laboratories, UK) slopes. These stock cultures were stored in the dark at $4^{\circ} \mathrm{C}$ until used.

Methods

Preparation methods of natural extracts

- Alcoholic extract: The plant powder (300 g) of each part was soaked in $1500 \mathrm{ml}$ ethanol for one week at room temperature with shaking day by day followed by filtration and again extraction for four times. (AbdelHameed et al.,2012)

- Cold aqueous extract: The extract was prepared by infusion from $260 \mathrm{~g}$ of dried leaves of $C$. erectus L. The material was weighed, ground and the infusion was performed by adding distilled water at room temperature for 30 minutes and stored at $5^{\circ} \mathrm{C}$.

- Hotaqueous extract: The extract was prepared by infusion from $260 \mathrm{~g}$ of dried leaves of $C$. erectus $\mathrm{L}$. The material was weighed, ground and the infusion was performed by adding distilled water at $100^{\circ} \mathrm{C}$ for 30 minutes. The aqueous extract was lyophilized and stored at $5^{\circ} \mathrm{C}$. (Nascimento et al., 2016).

Analysis methods

- Total phenols and flavonoids contents: Total phenols and flavonoids contents were described by Arnous et al. (2001) and Joyeux et al. (1995), respectively. 
- Determination of antioxidant activity: Antioxidant activity of Conocarpus erectus L. leaves extracts were determined by the 1,1-diphenyl-2-picryl-hydrazyl (DPPH) method according to (Brand-Williams et al., 1995).

- Determination of Chlorophyll A, chlorophyll $B$ and carotenoids: Chlorophyll A, chlorophyll B and carotenoids were determined as described by Arnon (1949) and Wettstein (1957), respectively.

- HPLCanalysis of Polyphenols and flavonoids: Polyphenols and flavonoids contents in the extracts of Conocarpus erectus L. leaves were determined using HPLC (Agilent series 1200). Column temperature was maintained at 35 . gradient separation was carried out with methanol and acetonitrile as a mobile phase at flow rate of $1 \mathrm{ml} / \mathrm{min}$. This method modified of (Goupy et al., 1999) and (Mattilla et al., 2000), respectively.

- Determination of total tannins: Tannins contents in the extracts of Conocarpus erectus L. leaves were determined by vanillin hydrochloric acid method described by (price et al., 1978).

\section{Antimicrobial activity}

Antimicrobial activity was determined using the agar well diffusion assay method as described by Holder and Boyce (1994). DMSO was used as a negative control. Bacterial cultures were incubated at $37^{\circ} \mathrm{C}$ for $24 \mathrm{hr}$. Antimicrobial activity was determined by measurement zone of inhibition (Agwa et al., 2000).

\section{Determination of anticancer activity}

Effect of Conocarpus erectus L. leaves extracts as anticancer measurement of potential cytotoxicity activity against the breast carcinoma cell line (MCF7) and liver carcinoma cell line (HEPG2) were tested by SRB assay using the method of Skehane et al. (1990).

Statistical analysis: The obtained data were exposed analysis of variance. Duncan's Multiple range tests at $(p \leq 0.05)$ level was used to compare between means. The analysis was carried out using the PRO-ANOVA procedure of Statistical Analysis System (SAS, 1996).

\section{Results and Discussion}

Antioxidant activity of Conocarpus erectus L. leaves

The total amounts of phenols, flavonoid and tannin components of ethanolic,cold aqueous and hot water aqueous extracts fractions were chemically estimated. Table 1 showed that the hot water extract fraction of leaves contains high total phenolic contents equivalent to $211.7 \mathrm{mg} / \mathrm{g}$ GAE whereas the Cold aqueous extract fractions of leaves has the lowest total phenolic contents (186.2mg/g GAE). On the other hand the ethanolic extract fraction of leaves has the highest total flavonoid contents equivalent to $57.2 \mathrm{mg} / \mathrm{g} \mathrm{RE}$ followed to cold aqueous extract $27.6 \mathrm{mg} / \mathrm{g}$ RE. The estimation of total tannin showed high content of the ethanolic extract than lack gradual in cold aqueous extract and hot aqueous extract. The model of scavenging of the stable DPPH radicals is awidely method to evaluate the antioxidant activity of the investigated sample in relatively short time compared with other methods. The effect of antioxidants on DPPH radical scavenging is thought to be due to their hydrogen donating ability. DPPH is a stable free radical and accepts an electron or hydrogen radical to become a stable diamagnetic molecule (Gulcin et al., 2004). The addition of the investigated extracts to the DPPH solution caused a decrease in the optical density at $517 \mathrm{~nm}$ (the maximum absorption of a stable DPPH radical at $517 \mathrm{~nm}$ ). The decrease in absorbance of DPPH radical caused by antioxidants is due to the reaction between antioxidant molecules and radical which results in the scavenging of the radical by hydrogen donation. This is visualized as a discoloration from purple to yellow. The total antioxidant activity was the highest in ethanolic extract $66.7 \%$ and it was not signaficant in cold and hot water extract $51 \%$ and $44 \%$, respectively. The activities of extracts were in order :ethanolic exectract $>$ hot water extract $>$ cold water extract leaves. This result is agreement with (Madsen et al., 1996) who reported that phenol and flavonoid compounds play an important role as antioxidants and a good correlation between the concentration of plant phenolic and the total antioxidant capacity. These data are in harmony to those of GallegosInfant et al. (2010) who found that temperature affects on the total phenolic content positively, higher temperatures, higher phenolic contents were observed and (Seok-Moon et al., 2004) who indicated that total phenol contents and the antioxidants activity were significantly affected by heating temperature and duration of treatment and the heating process can be used as a tool for increasing the antioxidant activity. 
TABLE 1. Antioxidant activity of Conocarpus erectus $\mathrm{L}$. leaves extracts.

\begin{tabular}{|c|c|c|c|}
\hline \multirow[b]{2}{*}{ Antioxidant activity } & \multicolumn{3}{|c|}{ Conocarpus erectus L. leaves } \\
\hline & EOH & CAE & HAE \\
\hline $\begin{array}{l}\text { Total phenols(mg gallic acid } \\
\text { equivalents/g plant extract) }\end{array}$ & $206.5^{\mathrm{a}} 6.30$ & $186.2^{\mathrm{b}} 3.02$ & $211.7_{ \pm}^{\mathrm{a}} 2.4$ \\
\hline $\begin{array}{l}\text { Flavonoids (mg rutine } \\
\text { quivalents/g plant extract) }\end{array}$ & $57.2_{ \pm}^{\mathrm{a}} 2.10$ & $27.6^{\mathrm{b}} 0.38$ & $17.6_{ \pm}^{\mathrm{c}} 1,5$ \\
\hline $\begin{array}{c}\text { Total antioxidant activity } \\
(\%)\end{array}$ & $89.5^{\mathrm{a}} 4.00$ & $66.01^{\mathrm{c}}{ }_{ \pm} 1.8$ & $69.78^{\mathrm{b}} 5.2$ \\
\hline $\begin{array}{l}\text { Total tannins (mg gallic acid } \\
\text { Plant part equivalents/g plant } \\
\text { extract)a equivalents/g plant } \\
\text { extract)b equivalents/g plant } \\
\text { extract) }\end{array}$ & $66.7_{ \pm}^{\mathrm{a}} 0.13$ & $51_{ \pm}^{\mathrm{b}} 0.11$ & $44_{ \pm}^{\mathrm{c}} 0.3$ \\
\hline
\end{tabular}

Values are means of three replicates ${ }_{ \pm} \mathrm{SE}$.

Values followed by the same letters within the same row were not significantly different at 0.05 level

$\mathrm{EOH}$ (ethanolic extract)

CAE (cold aqueous extract)

HAE (hot aqueous extract)

Chlorophyll A, B and carotenoids ( $\mathrm{mg} / 100 \mathrm{~g})$ in Conocarpus erectus L. leaves extracts

As shown in Table 2 chlorophyll A, B and Carotenoids. It could be , noticed that chlorophyll $\mathrm{A}, \mathrm{B}$ and Carotenoids $(\mathrm{mg} / 100 \mathrm{~g})$ were highest in ethanolic extract were $(0.68,0.13$ and 0.06 $\mathrm{mg} / 100 \mathrm{~g}),(0.16,0.12$ and $0.03 \mathrm{mg} / 100 \mathrm{~g})$ and ( $0.087,0.016$ and 0.011$)$, respectively, followed by cold aqueous extract then hot aqueous extract .These results are in harmony to Hande et al., (2008) who reported that chlorophylls are easily degraded by heat.

The concentration of phenolic compounds found in Conocarpus erectus L. leaves extracts

The concentrations of identified components were determined using the obtained calibration curves and listed in Tables 3 and 4. Most of phenolic compounds selected in Table 3 were identified in each sample. In the present study, pyrogallol, caffeine and e- vanillic were the major phenolic compounds 3500, 730 and $1020 \mathrm{ppm}$, respectively in ethanolic extract but the major phenolic compounds in cold aqueous extract were pyrogallol, Salicylic, epi- catachin gallic and protocatchouic 870,320,210, 163 and 110 ppm, respectively. It also could be noticed that gallic, pyrogallol, protocatchouic, chlorogenic, catechol, catechin, caffeic, 4- amino benzoic acid, ferulic, iso-ferulic, epi- catachin, ellagic , alpha- coumaric, salycillic, 3,4,5 methoxy, cinnamic, coumarin, $\mathrm{p}$ - coumaric and cinnamic were higher in hot aqueous extract than cold aqueous extract.

The concentration of flavonoid compounds of Conocarpus erectus L. leaves extracts

The results in Table 4 indicated that ethanolic extract was rich in flavonoids for each aqueous extracts and the highest concentration being rosmarinic (1060 ppm) forward to quercetrin and quercitin (230 and $120 \mathrm{ppm}$ ). While the cold aqeous extract was the highest in hesperidin rosmarinic and luteolin 140,30 and 30 , respectively. It could be also, noticed that the lowest amount of flavonoids in hot aqueous extract. Inderjit, 1991 revealed that hesperidin is a naturally occurring bioflavonoid, a compound in plants with antioxidant properties. Bioflavonoid also provide the color, flavor and aroma to plant. It is commonly referred to as vitamin P. it is'not naturally occur in the body ; you can only get it through foods or synthetic supplement. Rosmarinic solubility in water slightly soluble and well soluble in most organic solvents, in plants it is supposed to act as a preformed constitutively accumulated defense compound (Petersen et al., 2003). luteolin is often glycosylated in plants, and the glycoside is hydrolyzed to free luteolin during absorption (Mann, 1992).

Egypt. J. Food Sci. 46 (2018) 
TABLE 2. Chlorophyll A, B and Carotenoids $(\mathrm{mg} / 100 \mathrm{~g})$ in Conocarpus erectus L. leaves extracts.

\begin{tabular}{|l|c|c|c|}
\hline \multirow{2}{*}{\multicolumn{1}{c|}{ Item }} & \multicolumn{3}{|c|}{ Concentration (mg/100g) } \\
\cline { 2 - 4 } & EOH & CAE & HAE \\
\hline Chlorophyll A & $0.68^{\mathrm{a}} \pm 0.006$ & $0.16^{\mathrm{b}} \pm 0.005$ & $0.087^{\mathrm{c}} \pm 0.005$ \\
\hline Chlorophyll B & $0.13^{\mathrm{a}} \pm 0.007$ & $0.12^{\mathrm{b}} \pm 0.005$ & $0.016^{\mathrm{c}} \pm 0.007$ \\
\hline Carotenoids & $0.06^{\mathrm{a}} \pm 0.007$ & $0.03^{\mathrm{b}} \pm 0.007$ & $0.011^{\mathrm{c}} \pm 0.006$ \\
\hline
\end{tabular}

Values are means of three replicates ${ }_{ \pm} \mathrm{SE}$.

Values followed by the same letters within the same row were not significantly different at 0.05 level

$\mathrm{EOH}$ (ethanolic extract)

CAE (cold aqueous extract)

HAE (hot aqueous extract)

TABLE 3. The concentration of phenolic compounds found in Conocarpus erectus $\mathrm{L}$. leaves extracts.

\begin{tabular}{|c|c|c|c|}
\hline \multirow{2}{*}{ phenolic compounds } & \multicolumn{3}{|c|}{ Concentration (ppm) } \\
\hline & ЕОН & CAE & HAE \\
\hline Gallic & $170^{\mathrm{a}}$ & $163^{\mathrm{b}}$ & $170^{\mathrm{a}}$ \\
\hline Pyrogallol & $3500^{\mathrm{a}}$ & $870^{\mathrm{c}}$ & $1414^{b}$ \\
\hline 3- hydroxytyrosol & $30^{\mathrm{a}}$ & $30^{\mathrm{a}}$ & -- \\
\hline Protocatchouic & $380^{\mathrm{a}}$ & $110^{\mathrm{c}}$ & $160^{\mathrm{b}}$ \\
\hline Chlorogenic & $230^{\mathrm{b}}$ & $160^{c}$ & $290^{\mathrm{a}}$ \\
\hline Catechol & $190^{\mathrm{b}}$ & $14^{c}$ & $212^{\mathrm{a}}$ \\
\hline Catechin & $80^{\mathrm{a}}$ & $43^{c}$ & $65.4^{\mathrm{b}}$ \\
\hline Caffeine & $730^{\mathrm{a}}$ & $10^{\mathrm{b}}$ & -- \\
\hline Caffeic & $80^{\mathrm{b}}$ & $60^{c}$ & $115^{\mathrm{a}}$ \\
\hline P- OH benzoic & $290^{\mathrm{a}}$ & $30^{\mathrm{b}}$ & -- \\
\hline 4- amino benzoic acid & $250^{\mathrm{a}}$ & $140^{\mathrm{c}}$ & $224^{b}$ \\
\hline Vanillic & $90^{\mathrm{a}}$ & $4^{b}$ & -- \\
\hline Ferulic & $90^{\mathrm{b}}$ & $70^{c}$ & $100^{\mathrm{a}}$ \\
\hline Iso-ferulic & $10^{\mathrm{b}}$ & $2^{c}$ & $12^{\mathrm{a}}$ \\
\hline Epi- catachin & $200^{\mathrm{b}}$ & $210^{\mathrm{c}}$ & $290^{\mathrm{a}}$ \\
\hline Reversetrol & $20^{\mathrm{a}}$ & $1^{\mathrm{b}}$ & -- \\
\hline E- vanillic & $1020^{\mathrm{a}}$ & $20^{\mathrm{b}}$ & - \\
\hline Ellagic & $170^{\mathrm{a}}$ & $60^{c}$ & $160^{\mathrm{b}}$ \\
\hline Alpha- coumaric & $50^{\mathrm{a}}$ & $6^{c}$ & $30^{\mathrm{b}}$ \\
\hline Salycillic & $420^{\mathrm{b}}$ & $320^{\mathrm{c}}$ & $580^{\mathrm{a}}$ \\
\hline 3,4,5 Methoxycinnamic & $40^{\mathrm{a}}$ & $3^{c}$ & $20^{\mathrm{b}}$ \\
\hline Coumarin & $6^{\mathrm{b}}$ & $1^{\mathrm{c}}$ & $40^{\mathrm{a}}$ \\
\hline p- Coumaric & $40^{\mathrm{a}}$ & $12^{\mathrm{c}}$ & $30^{\mathrm{b}}$ \\
\hline Cinnamic & $40^{\mathrm{b}}$ & $22^{\mathrm{c}}$ & $42^{\mathrm{a}}$ \\
\hline Benzoic & $190^{\mathrm{a}}$ & $30^{\mathrm{b}}$ & -- \\
\hline
\end{tabular}

Values followed by the same letters within the same row were not significantly different at 0.05 level

$\mathrm{EOH}$ (ethanolic extract)

$\mathrm{CAE}$ (cold aqueous extract)

HAE (hot aqueous extract) 
TABLE 4. The concentration of flavonoid compounds of Conocarpus erectus $\mathrm{L}$. leaves extracts.

\begin{tabular}{|c|c|c|c|}
\hline \multirow{2}{*}{ Flavonoids } & \multicolumn{3}{|c|}{ Concentration (ppm) } \\
\cline { 2 - 4 } & \multicolumn{3}{|c|}{ HAE } \\
\cline { 2 - 4 } & \multirow{2}{*}{ EOH } & CAE & $0.3^{\mathrm{c}}$ \\
\hline Naringin & $20^{\mathrm{a}}$ & $4^{\mathrm{b}}$ & $3.3^{\mathrm{b}}$ \\
\hline Rutin & $40^{\mathrm{a}}$ & $2^{\mathrm{b}}$ & $101^{\mathrm{b}}$ \\
\hline Hesperidin & -- & $140^{\mathrm{a}}$ & $0.9^{\mathrm{c}}$ \\
\hline Rosmarinic & $1060^{\mathrm{a}}$ & $30^{\mathrm{b}}$ & $2.0^{\mathrm{c}}$ \\
\hline Quercetrin & $230^{\mathrm{a}}$ & $12^{\mathrm{b}}$ & $2.3^{\mathrm{b}}$ \\
\hline Quercitin & $120^{\mathrm{a}}$ & $3^{\mathrm{c}}$ & $0^{\mathrm{a}}$ \\
\hline Luteolin & -- & $39^{\mathrm{a}}$ \\
\hline Kaempferal & $60^{\mathrm{a}}$ & $1^{\mathrm{b}}$ & $1.9^{\mathrm{b}}$ \\
\hline Hespertin & $100^{\mathrm{a}}$ & $5^{\mathrm{b}}$ & $0.95^{\mathrm{b}}$ \\
\hline Apegenin & $30^{\mathrm{a}}$ & $1^{\mathrm{b}}$ & -- \\
\hline 7- Hydroxyl-flavone & $0.016^{\mathrm{a}}$ & $0.04^{\mathrm{a}}$ & \\
\hline
\end{tabular}

Values followed by the same letters within the same row were not significantly different at 0.05 level

$\mathrm{EOH}$ (ethanolic extract)

CAE (cold aqueous extract)

HAE (hot aqueous extract)

Antibacterial activity of extracts of Conocarpus erectus L. leaves on various clinical strains

Phytochemical constituents of medicinal plants are secondary metabolites that may act as antimicrobial agents (Marjorie, 1999). As shown in Table 5, aqueous extracts were active against for the tested bacteria (Bacillus ceries, Staph.aureus, E.coli and Salmonella typhimurium).The results indicated that the aqueos extracts of leaf crude were active in cold and hot extracts, therefore, extracts of crude leaf were more active in cold extract of hot extract in case of Staph.aureus.

extract of hot extract in case of Staph.aureus.

TABLE 5. Antibacterial activity of the extracts of Conocarpus erectus $L$. leaves on various clinical strains.

\begin{tabular}{|c|c|c|c|c|c|c|}
\hline \multirow{2}{*}{$\begin{array}{c}\text { Organisms } \\
\text { Bacterial }\end{array}$} & \multirow{2}{*}{$\begin{array}{l}\text { stains code } \\
\text { Control }\end{array}$} & \multirow{2}{*}{$\begin{array}{l}\text { Gram } \\
\text { Stain }\end{array}$} & \multirow{2}{*}{$\begin{array}{c}\text { Distilled } \\
\text { sterile water }\end{array}$} & EOH & CAE & HAE \\
\hline & & & & \multicolumn{3}{|c|}{ Inhibition zone diameter (mm) } \\
\hline Bacillus ceries & (ATCC-33018) & + & 0.00 & $1.2^{\mathrm{b}}$ & $1.7^{\mathrm{a}}$ & $1.6^{\mathrm{a}}$ \\
\hline Staph.aureus & (DSM-20231) & + & 0.00 & $1.4^{\mathrm{b}}$ & $1.8^{\mathrm{a}}$ & $1.3^{\mathrm{b}}$ \\
\hline E.coli & (ATCC -69337) & - & 0.00 & $1.6^{\mathrm{a}}$ & $1.36^{\mathrm{b}}$ & $1.53^{\mathrm{a}}$ \\
\hline $\begin{array}{c}\text { Salmonella } \\
\text { typhimurium }\end{array}$ & (ATCC-14028) & - & 0.00 & $1.0^{\mathrm{b}}$ & $1.5^{\mathrm{a}}$ & $1.5^{\mathrm{a}}$ \\
\hline
\end{tabular}

Values followed by the same letters within the same row were not significantly different at 0.05 level ( EOH (ethanolic extract

(CAE (cold aqueous extract

Egypt. J. Food Sci. 46 (2018) 
Efficiency of Conocarpus erectus L. leaves extracts as anticancer agent

In 2018, 1,735,350 new cancer cases and 609,640 cancer deaths are projected to occur in the United States (Siegel et al., 2018). Many people don't really know what cancer is? If a normal cell demonstrate, on the inside of the cell is the nuclei, that contains DNA and that DNA contains genes that control the action of the cell. The one of those important actions is how a cell makes a copy of itself. If a normal cell placed in culture it will simply make a copy of itself and if there's room those cells will make copies of themselves and they will keep doing that until they fill up that area. If one of those cells dies then an adjacent cell is going to jump into that cell cycle and it is going to fill that hole. That how we went from a zygote to the trillions of cells that are inside our body. Natural products sometime have therapeutic benefit but better as it is more effective and cause fewer side effects in treating diseases than the synthetic one. As mentioned before that secondary metabolism are group of organic compounds that are produced from the plant which are alkaloids, triterpenes, monotriterpense, flavonoids, essential oils, sterols, tannins and saponins each one has its own role in secondary metabolism that can affect in anti-proliferation of cancer cells (Hamed et al., 2016). According to world Health organization (WHO) the best source to obtain a variety of drugs is from medicinal plants. About $80 \%$ of individuals from developed countries use traditional medicines which have derived from natural plant products (Nagarajan et al., 2013).

Results in Table 6 showed that cytotoxic activity of Conocarpus erectus L. leaves as anticancer agent. As illustrated in Table 6, the most efficient cytotoxic activity of Conocarpus erectus L. leaves extracts was against (liver cancer) HEPG2 and (breast cancer) MCF7. Also, data indicated that the most efficient cytotoxic activity against (breast cancer) MCF7 in ethanolic extract with IC50 $=99$ followed by hot aqueous extract with IC50 $=100$ then cold aqueous extract with IC50 $=102$, while the most efficient cytotoxic activity against (liver cancer) HEPG2 in hot aqueous extract with $\mathrm{IC} 50=37.9$ followed by ethanolic extract with IC50 $=39.3$ then cold aqueous extract with IC50 $=50.9$.

The current result was confirmed by AbdelHameed et al. (2012) who reported that the cytotoxicity of the ethyl acetate and n-butanol fractions of the different parts of $\mathrm{C}$. erectus in HepG2 and MCF-7 cell lines by using the sulforhodamine $B(\mathrm{SRB})$ and also confirmed by Maryam. (2015) who showed high cytotoxic activity toward the HepG2 cell line of the stems and leaves of Conocarpus erectus L.

(HAE (hot aqueous extract

TABLE 6. Cytotoxic activity of Conocarpus erectus $\mathrm{L}$. leaves extracts.

\begin{tabular}{|c|c|c|c|c|c|c|}
\hline \multirow{3}{*}{$\begin{array}{c}\text { Concentration } \\
(/ / \mathrm{ml})\end{array}$} & \multicolumn{6}{|c|}{ Inhibition percent } \\
\hline & \multicolumn{3}{|c|}{$\begin{array}{c}\text { MCF7 } \\
\text { (breast) }\end{array}$} & \multicolumn{3}{|c|}{$\begin{array}{c}\text { HEPG2 } \\
\text { (liver) }\end{array}$} \\
\hline & $\mathrm{EOH}$ & CAE & HAE & $\mathrm{EOH}$ & CAE & HAE \\
\hline 0.0 & 0.00 & 0.00 & 0.00 & 0.00 & 0.00 & 0.00 \\
\hline 12.0 & 4.2 & 3.8 & 5 & 13.2 & 8.5 & 11.9 \\
\hline 25.0 & 12.6 & 10.1 & 11.4 & 39.9 & 36.8 & 40.2 \\
\hline 50.0 & 39.8 & 30 & 40.4 & 57.3 & 50.6 & 53.5 \\
\hline 100.0 & 40.2 & 40.1 & 40.2 & 72.6 & 68.5 & 70.4 \\
\hline IC 50 & 99 & 102 & 100 & 39.3 & 50.9 & 37.9 \\
\hline
\end{tabular}

MCF7 (breast carcinoma cell line)

HEPG2 (liver carcinoma cell line )

$\mathrm{EOH}$ (ethanolic extract)

CAE (cold aqueous extract)

HAE (hot aqueous extract) 


\section{Conclusion}

From the aforementioned results, the extracts of Conocarpus erectus leaves present antioxidant, antimicrobial and anticancer properties, it could be concluded that the leaves extract can be used as a natural food additives instead of artificial food additives because of its negative effect on human health. and these findings contribute to scientific information for the effectiveness on use of this plant in the development of a phytotherapic compound.

\section{References}

Abdel-Hameed, E. S., S. A. Bazaid, M. M. Shohayeb, M. M. El-Sayed, and El- Wakil, E.A.(2012) Phytochemical Studies and Evaluation of Antioxidant, Anticancer and Antimicrobial Properties of Conocarpus erectus L. Growing in Taif, Saudi Arabia. European Journal of Medicinal Plants, 2(2),93-112.

Abdel-Hameed, E.S. ; Bazaid,S.A.and Sabra, N.A. (2013) Protective Effect of Conocarpus erectus Extracts on CCl 4-Induced Chronic Liver Injury in Mice. Global Journal of Pharmacology 7 (1), 52 60.

Agwa H, Aly MM.and Bonaly R (2000) Isolation and characterization of two Streptomyces species produced non polyenic $J$. Union Arab Biol. 7, 62-82.

Arnon D.I. (1949) Copper enzymes in isolated chloroplasts polyphenoloxidase in beta vulgar. Plant physiol. 24(1), 1-15.

Arnous, A.; Makris, D. P., and Kefalas, P. (2001) Effect of principal olyphenol components in relation to antioxidant characteristics of aged red wines. $J$. Agric. Food Chem. 49(12), 5736-5742.

Brand-Williams, W., Cuvelier, M. E., and Berset, C. (1995). Use of a free radical method to evaluate antioxidant activity. J. Food Sci. and Technol. 28(1), 25-30.

Bailey LH (1976) Hortus Third: A Concise Dictionary of Plants Cultivated in the United States and Canada. New York, MacMillan Collier MacMillan, p.306.

Daniela, D., Marina, D., Irene, S., Mirela, B., Monica, R.,Kamal, D. and Terezinha, D. (2016) The Microbial Quality Aspects and Decontamination Approaches for the Herbal Medicinal Plants and Products: An in-Depth Review, Current Pharmaceutical Design, 22(27),4264-4287.
Duke, J. A. and Wain, K. K. (1981) Medicinal plants of the World: Computer index with more than 85,000 entries.3, 1654

Gallegos-Infant, J.A., Rocha-Guzman, N.E., Gonzalez-Laredo, R.F. ,Ochoa- Martínez L.A.,Corzo N. , Bello-Perez L.A., Medina-Torres L. and Peralta-Alvarez L.E. (2010) Quality of spaghetti pasta containin Mexican common bean flour (Phaseolus vulgaris L.).Food Chemistry 119(4), 1544-1549.

Goupy, P., Hugues, M., Biovin, P. and Amiot, M. J.(1999) Antioxidant composition and activity of barley (Hordeum vulgare) and malt extracts and of isolated phenolic compounds. J. Sci. Food Agric., 79 (12),1625-1634.

Gulcin, I.G., Sat, S.B., Elmastas, M., Kufreviouglu, O.I. (2004)Comparison of antioxidant activity of Clove (Eugenia Caryophylata Thunb) buds and lavender (Lavandulas toechas L). Food Chem., 87(3), 393-400.

Hamed, M.M., Mohamed, M.A., Ibrahim, M.T. (2016) Cytotoxic activity assesment of secondary metabolites from Tecomaria capensis v. aurea. International Journal of Pharmacognosy Phytochemical Research, 8 (7),1173-1182.

Hande, S. E.; Feryal, K.; Nuray, K. and Yesim, S. (2008) Effect of HeatTreatment on chlorophyll degradation and color loss in green peas. Research article. J. of GIDA 33 (5), 225-233.

Holder, I.A and Boyce, S.T. (1994). Agar well diffusion assay testing of bacterial susceptibility to various antimicrobials in concentrations non-toxic for human cells in culture. Burns 20(5),426-429.

Inderjit, K. M. (1991) Hesperetin 7-rutinoside (hesperidin) and taxifolin 3- arabinoside as germination and growth inhibitors in soils associated with the weed, Pluchea| anceolata (DC) C.B. Clarke (As teraceae) J. Chem Ecol., 17 (8) : 1585-91.

Irvine, F. R. (1961) Woody plants of Ghana with special reference to their uses. Oxford University Press, London, pp 868.

Joyeux, M., Lobystein, A., Anton, R. and Morier, F. (1995) Comparative antilipoperoxidant, antinecrotic and scavenging potencies of terpenes and bioflavones from gingko and some flavonoids. Planta Med. 61 (2),126-129. 
Madsen, H. L., Nielsen, G., and Skibsted, L. H. (1996) Screening of antioxidative activity of spices. Acomparison between assay based on ESR spin traping and electrochemical measurement of oxygen consumption. Food Chem. 57(2): 331-337.

Mann, J. (1992) Secondary Metabolism (2 ${ }^{\text {nd }}$ ed.). Oxford, UK: Oxford University Press. pp. 279-280. ISBNO-19-855529-6.

Marjorie M.C. Plant products as antimicrobial agents. ClinMicrobiol Rev. 12,564-582, 1999.

Marjorie, M.C. (1999) Plant products as antimicrobial agents. Clin.Microbiol.Rev., 12 (4), 564-582.

Marja, P. K., Anu, I. H., Heikki, J. V., Jussi-Pekka, R., Kalevi, P.,Tytti, S. K.and Marina, H. (1999). Antioxidant activity of plant extracts containing phenolic compounds. Journal of Agricultural and Food Chemistry, 47, 3954-3962.

Maryam ,B., Uzair, M. and Chaudhry, B. A. (2015) A review of phytochemical and biological studies on Conocarpus erectus (Combretaceae). Pakistan Journal of Pharmaceutical Research, 1(1), 1-8.

Mattila, P., Astola, J. and Kumpulainen, J.(2000) Determination of flavonoids in plantmaterial by HPLC with diode-array and electro-array detections. J. Agric. Food Chem. 48(12):58345841.

Nagarajan, M., Rajasekaran, S., Ganesh, S.K. (2013) Antibacterial activity of Lawsonia inermis L. International Journal of Modern Biology Medicine. 4, 169-175.

Nascimento,D., De Souza,I.A., Barbosa, M.O. Santana,M.A.N., Júnior, D.F.P., Lira, E.C., Vieira, J.R.C. (2016) Phytochemical Screening and Acute Toxicity of Aqueous Extract of Leaves of Conocarpus erectus Linnaeus in Swiss Albino Mice. An. Acad. Bras. Ciênc. vol.88, no.3 Rio de Janeiro Sept. Epub Aug 04.

Petersen, M. and Simmonds, M.S.J. (2003) Rosmarinic acid. Phytochemistry, 62(2), $121-125$.

Saroya, A.S. (2011) Herbal Drug Industry, In: Saroya AS, Ed.Herbalism, Phytochemistry and Ethnopharmacology.Enfield, USA: Science Publishers; p. 17. Res. Commun. 204, 578-584.

Seok-Moon, J.; So-Young, K.; Dong-Ryul, K.; SeongChun J; Nam, K.C. and Seung-Cheol, L. (2004). Effect of Heat Treatment on the Antioxidant Activity of Extracts from Citrus Peels. J. Agric. Food Chem. 52 (11),3389-3393.

Shohayeb, M., Abdel-Hameed,E. and Bazaid,S.(2013). Antimicrobial activity of tannins and extracts of different parts of conocarpus erectus L. IJPBS. APR-JUN 3(2), 544-553.

Siegel, R.L., Miller, K.D.and Jemal, A. (2018) Cancer Statistics, Surveillance and Health Services Research, American Cancer Society.

Skehan P., Storang R., Scudiero D., Monks A., McMahon J., Vistica D., Warren J.T., Bokesch H., Kenney S. and Boyd M.R. (1990). Newcoloremtric cytotoxicity assay for anti-cancer drug screening. $J$ Natl Cancer Inst. 82(13),107-1112.

Wettstein, D.V. (1957). Determination of carotenoides in plants. Experimenal cell Res. 12, 427-430.

WHO (2007) World Health Organization guidelines for assessing quality of herbal medicines with reference to contaminants and residues; p. 213. 
النثاط المضاد للأكسدة و الميكرويات و الأورام لمستخلصات أوراق نبات الكربس المصري

غادة حسين حامد إسماعيل

معهد بحـوث تكنولوجيا الأغذية - مركز البحـوث الزراعية

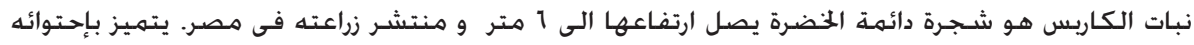

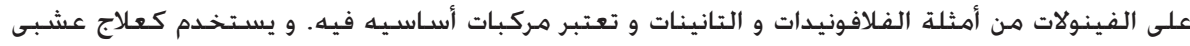

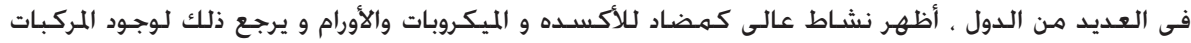

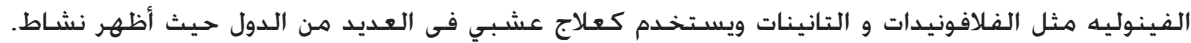

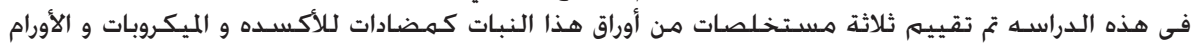

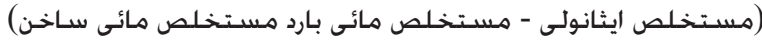

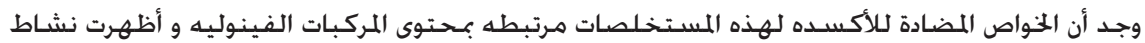

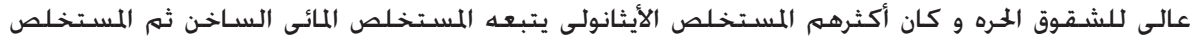

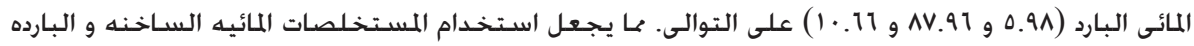

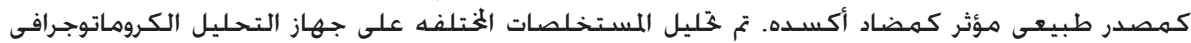

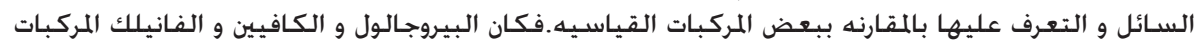

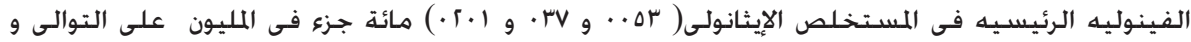

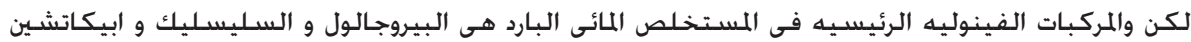

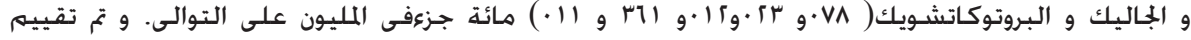

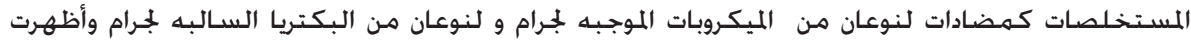

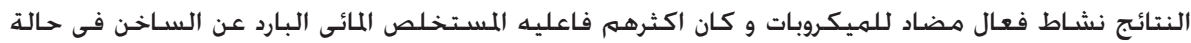
استافيلو كوكس اريوس.

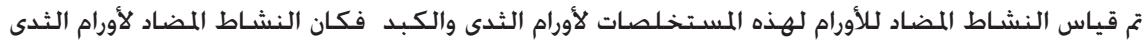

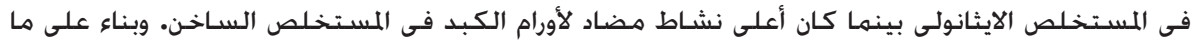

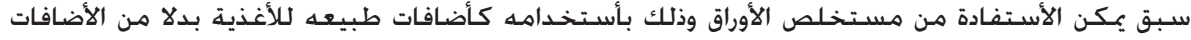

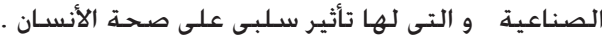

